\title{
TIPE DAN GAYA KEPEMIMPINAN PENDIDIKAN DAN DAKWAH
}

\author{
Nadzmi Akbar \\ UIN Antasari Banjarmasin
}

\begin{abstract}
Leadership style adopted by a leader in educational institutions, will mentukan atmosphere and climate in the next educational institutions also determine the effectiveness of health efforts in the purpose of education. Leadership is born with a process, not innate from birth to be able and trained to achieve the competence of leadership that berkulaitas, so that in the institutional education can achieve optimal effectiveness.

The style of leadership is the way used in the leadership process that is implemented in a person's task to face each other for what he wants. There are two styles of leadership that is style of leadership style, leadership style, leadership style. Dakwaha leadership style is a leader who is able to bring society to success in the pleasure of Allah SWT. In this case the leader will always appear to achieve the benefit and welfare of his followers for the salvation of the life of the world and the hereafter. Thus the style seoarang da'wah leaders and education will not be separated from three things as a mentor, as a model and as a practitioner. Dakwah leadership style is a model and style of leadership with its own formulation.
\end{abstract}

Keywords: leadership, education, da'wah

Pendahuluan

Pada suatu lembaga

kepemimpinan

menentukan

kedinamisan jalannya organisasi, pada

pemimpinlah lembaga diserahkan, dan

menjadi tanggung jawab pemimpin

untuk mencapai tujuannya. Tipe dan

Gaya, karakter dan kometmen pemimpin akan menjadi penentu bagi keberhasilan sebuah lembaga atau organisasi.

Tipe dan gaya kepemimpinan pada dasarnya akan merujuk cara pemimpin mempengaruhi secara otoriter dan mempengaruhi personel dengan mengikuti tipe dan gaya 
personel.Bermuara dari 2 gaya itulah akan diperoleh berbagai tipe dan gaya yang diperankan oleh seorang pemimpin.

Tipe dan gaya kepemimpinan yang diperankan agar dapat mencapai efektifitas organisasi, bagi personel yang memiliki karakter berbeda-beda dan unik. Seiring perkembangan zaman, ilmu pengetahuan dan teknologi yang berpengaruh terhadap daya nalar dan emosi personel, pemeimpin harus mampu membawa ke efektifan organisasi dengan tipe dan gaya pemimpin yang mampu menggerakan para personel untuk mencapai tujuan organisasi.

Pemimpin yang efektif harus mampu memerankan berbagai tipe dan gaya kepemimpinan, sebab setiap tipe dan gaya kepemimpinan memiliki kelebihan dan kelemahan. Dalam setiap ruang dan waktu yang berbeda memiliki iklim organisasi yang dinamis, harus diimbangi dengan tipe dan gaya kepemimpinan yang juga dinamis.

\begin{tabular}{|c|c|c|c|c|}
\hline Dalam & persfektif & dakwah & Dalam & mendefinisikan \\
\hline
\end{tabular}

pemimpin yang mampu membawa masyarakat kepada kesuksesan dalam mendapat ridha dari Allah SWT. Dalam hal ini pemimpin akan selalu berupaya untuk mencapai kemaslahatan dan kesejahteraan pengikutnya demi keselamatan hidup dunia dan akhirat. Dengan demikian gaya seoarang pemimpin dakwah dan pendidikan tidak akan terlepas dari tiga hal yaitu sebagai pembimbing, sebagai model dan sebagai praktisi. Segala kebaikan yang dimiliki oleh pemimpin akan ditranformasikan kepada bawahannya, sehingga semua memiliki tanggung jawab sebagaimana pemimpin.

\section{Pembahasan}

\section{A. Definisi Kepemimpinan}

Sebelum masuk kepada tipe dan gaya kepemimpinan terlebih dahulu penulis kemukakan tentang definisi kepemimpinan. Hal ini akan lebih mempermudah memahami tipe dan gaya kepemimpinan yang akan dibahas.
Dalam para ahli 
mengemukakan pendapat yang beragam, bahkan hampir tidak ada kata sepakat yang begitu persis dalam merumuskan definisi kepemimpinan.

Berikut ini dikemukakan beberapa pendapat para ahli tentang kepemimimpinan antara lain menurut George R. Terry (yang dikutip dari Sutarto, 1998 : 17) Kepemimpinan adalah hubungan yang ada dalam diri seseorang atau pemimpin, mempengaruhi orang lain untuk bekerja secara sadar dalam hubungan tugas untuk mencapai tujuan yang diinginkan.

Leadership is the process of giving purpose (meaningful direction) to collective effort, and causing willing effortto expended to achieve puepose (Gary Yukl, 2002 : 3). Kepemimpinan adalah proses memberikan tujuan (arah yang berarti) ke usaha kolektif,yang menyebabkan adanya usaha yang dikeluarkan untuk mencapai tujuan.
Gibson dkk dalam Hadari Nawawi (2003 : 21)berpendapat bahwa kepemimpinan adalah upaya menggunakan berbagai jenis pengaruh yang bukan paksaan untuk memotivasi anggota organisasi untuk mencapai tujuan tertentu.

Andrew J. Dubrin menyatakan bahwa kepemimpinan adalah kemampuan untuk menciptakan rasa percaya diri dan dukungan di antara bawahan agar tujuan organisasi dapat tercapai. Dalam kata lain, tugas pemimpin adalah menjaga keutuhan kerjasama karyawan yang bekerja dalam organisasi (2005 : 4).

Kepemimpinan adalah usaha untuk menggerakan manusia untuk mencapai tujuan tertentu baik bersifat dunia maupun ukhrawi sesuai dengan nilai dan syariat Islam (Muhammad al Suaidan $2005: 42)$. 
Secara singkat charkes J. Keating (2003: 9) berpendapat kepemimpinan adalah proses dengan berbagai cara mempengaruhi kelompok orang untuk tujuan bersama.

Dengan demikian kepemimpinan dapat didefinisikan sebagai usaha mempengaruhi sekelompok orang/anggota kelompok dengan gaya dan cara metode apa saja agar kelompok orang/anggota kelompoktersebut melakukan aktivitas untuk mencapai tujuan bersama.

Gaya dan cara atau metode yang digunakan sebagai pemimpin dalam konteks kepemimpinan saat ini adalah yang tidak bersifat memaksa, tidak bertentangan dengan hak azasi manusia bahkan harus lebih bersifat humanis. Dengan adanya beberapa definisi kepemimpinan tersebut di atas akan akan tercermin dalam dinamika kepemimpinan yang berkembang dari masa ke masa.

\section{B. Dinamika Kepemimpinan}

Pemimpin dalam manajemen memegang peranan untuk menggerakan seluruh sumber daya yang ada pada organisasi(Robert Krietner, 1989 : 9). Dalam hal ini pemimpin harus mampu mempengaruhi personelnya menuju keefekifan organisasu.Manajemen tidak hanya dipandang sebagai ilmu, melainkan juga sebagai seni. Stoner (2006:15) menyatakan bahwa manajemen sebagai "The art of getting things done through people”. Kepemimpinan adalah sebuah aktivitas "orang-orang", berbeda dari pekerjaan administratif dengan kertas atau aktifitas penyelesaian masalah. Kepemimpinan adalah dinamis dan melibatkan penggunaaan wewenang (Daft, Richard L. 2006 : 313).

Kemampuan untuk memimpin kadang-kadang dilihat sebagai kualitas kepribadian seseorang baik tidak atau tidak 
memiliki. Ada gagasan kebenaran dalam hal ini dan beberapa pemimpin brilian telah mencapai keberhasilan karena karisma pribadi dan visi mereka ditetapkan sebelum pengikut mereka.

Ada beberapa pemimpin yang memiliki kemampuan berpikir cepat dan memiliki intuisi sehingga mampu mengambil keputusan dengan cepat dan tepat pemikiran intuitif sering dilihat sebagai misterius dan bahkan pemikiran magis karena terjadi dengan cepat, tanpa berpikir logis jelas, dan ketika digunakan oleh para ahli, sering benar dalam kesimpulannya. Hebert Simon (1987) adalah salah satu ulama pertama yang mengungkap intuisi. Dalam studinya pemain catur ahli, misalnya, ia menemukan bahwa Grandmaster bisa membuat gerakan terampil dalam beberapa detik hanya dengan melirik posisi di papan dan kemudian memilih langkah selanjutnya. Dengan kata lain, mereka membuat cepat decikeputusan dengan analisis tampaknya sedikit; yaitu, mereka intuitif dan benar dalam pemikiran mereka dan memutuskan.

Tapi setelah pemeriksaan lebih dekat, intuisi tersebut adalah ahli pengetahuan hasil dan pengalaman (Epstein, 2010; Klein, 2003; Simon, 1987, 1992). pemikiran intuitif didasarkan pada asosiasi dan pengenalan pola. Simon (1992) secara ringkas menjelaskan: "Situasi telah memberikan isyarat: isyarat ini telah memberikan akses ahli untuk informasi yang tersimpan dalam memori, dan informasi yang memberikan jawabannya." (F. Dipaola, Wayne K Hoy, 2015 : 4). Secara singkat Hugges dkk (2012 : 1) menyatakan bahwa kepemimpinan adalah proses, bukan jabatan. Proses yang mempengaruhi terbentuknya tipe dan gaya kepemimpinan, dalam proses tersebut terdapat situasi, pengikut, pemimpin. Jika dirinci pada aspek situasi meliputi tugas, stres, lingkungan, iklim dan lainlain. Pada aspek pengikut meliputi 
nilai-nilai, norma, kekompakan dan lain-lain. Pemimpin meliputi sifat kepribadian, kecerdasan, keahlian dan lain-lain.

Menurut

Habsari

Kepemimpinan itu merupakan proses menggerakkan orang lain ke arah yang sama tanpa ada paksaan, hal ini dikarenakan adanya kepercayaan orang terhadap kepemimpinannya. Pemimpin yang memiliki karakteristik yang kuat dan memiliki daya pengaruh tinggi tentunya sangat dibutuhkan di lembaga pendidikan untuk dapat mencatatkan sejarahnya. Hal ini dikarenakan pendidikan merupakan sesuatu yang paling esensisal untuk perkembangan manusia (Yunus, Jamalulail 2009 : 4).

Dalam beberapa organisasi seorang pemimpin sekaligus menjadi seorang manajer, lalu apakah sama kemampuan dan kinerja pemimpin dengan manajer. Ada beberapa perbedaan antara manajer dengan pemimpin yaitu :
- Manajer melaksanakan, pemimpin berinovasi.

- Manajer memelihara, pemimpin mengembangkan.

- Manajer mengontrol, pemimpin menginpirasi.

- Manajer bertanya bagaimana dan kapan, pemimpin bertanya apa dan mengapa.

- Manajer meniru,pemimpin menciptakan sesuatu yang original.

- Manajer menerima status quo, pemimpin menantang. (Hughes dkk, 2012 : 10).

Pada lembaga pendidikan pada umumnya kepala sekolah bertindak sebagai pemimpin sekaligus juga bertindak sebagai manajer.Sehingga kepemimpinan pada lembaga pendidikan (kepala sekolah) harus mempunyai kemampuan membedakan dan sekaligus memadukan antara tugasnya sebagai manajer dan pemimpin di sekolahnya. 


\section{Tipe dan Gaya Kepemimpinan}

Setiap pemimpin memiliki gaya yang berbeda apakah demokratis atau otoriter. Tetapi, ada satu aspek pemimpin yang menonjol, yaitu pancaran kewibawaan (Timpe,2002 dalam Yunus, Jamalulail 2009 : 3). Artinya dalam setiap tipe dan gaya kepemimipinan apapun kulitas universal seorang pemimpin harus terlebih dahulu dipenuhi.

Pemimpin harus memiliki kualitas dasar yang meliputi kemampuan memerintahkan dengan cara hormat, yakin atas tujuan yang tulus, percaya akan kemampuan diri, kemampuan untuk menyampaikan pendapat, dapat diterima sebagai pemimpin, siap untuk berkorban, pemikiran yang terbuka, paham atas tanggung jawab serta tentunya memiliki jiwa optimis (Yunus, Jamalulail 2009 : 8).

\begin{tabular}{llr}
\multicolumn{1}{c}{ Sebagai } & pemimpin & dalam \\
kelompok & orang & akan \\
menampilkan & tipe dan & gaya
\end{tabular}

kepemimpinan yang di anggap akan efektif bagi pencapaian tujuan organisasi. Dari hasil penelitian menunjukan bahwa pada saat melakukan hal-hal yang luar biasa dalam organisasi, pemimpin menggunakan Lima Praktik Kepemimpinan Teladan ini :

- Mencontoh caranya

- Menginspirasi visi bersama

- Menantang proses

- Memungkinkan orang lain bertindak

- Menyemangati Jiwa (Kouzes, M James dan Barry Z. Posner2004 : 13).

Beberapa kualitas lainnya diperoleh melalui konsensus, tapi apa yang paling orang cari dan kagumi dari seorang pemimpin selalu sama. Seperti data yang dengan jelas menunjukkkan, agar orang sudi menuruti seseorang, mayoritas pengikut harus percaya bahwa pemimpinnya :

- Jujur

- Berorientasi ke depan

- Kompeten 
- Membangkitkan semangat (

Kouzes, M James dan Barry Z.

Posner2004 : 26).

Perkembangan

gaya

kepemimpinan selalu berkembang mulai dari gaya yang didasarkan oleh otoriter dan demokratis dari gaya dilayani dan melayani sehingga ada istilah gaya kepemimpinan pelayanan. Gaya kepemimpinan pelayanan yang merupakan gaya kepemimpinan yang bersumber dari perasaaan yang tulus yang timbul dari hati yang paling dalam yang memiliki kehendak untuk menjadi pihak pertama yang dapat melayani siapa saja yang memiliki hubungan organisasi yang ia pimpin, sehingga ada kepuasan pada jiwanya ketika ia mampu memberikan pelayanan yang terbaik kepada orang lain (Yunus, Jamalulail 2009 : vii).

Secara global tipe dan gaya kepemimpinan sebenarnya juga dipengaruhi oleh jenis kepemimpinan yang juga dianggap sebagai kualitas kepemimpinan seseorang, sebagaimana bagan dibawah ini :

\section{Gambar 1.}

Karakteristik dan Kualitas Kepemimpinan

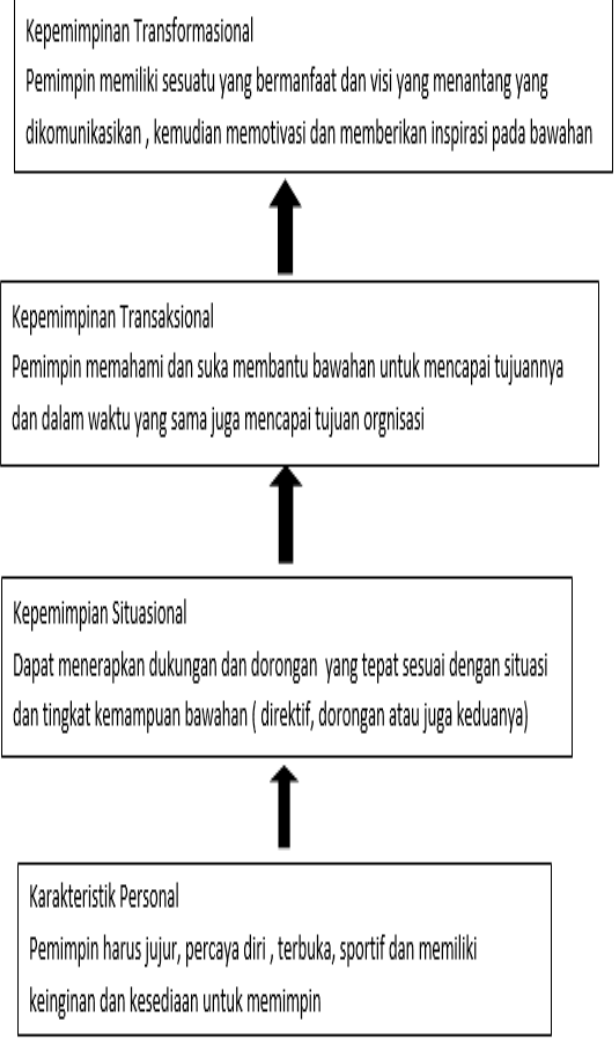

Sumber: Cacioppe (1997 : 24)

Kepemimpinan transaksional lebih mendekati asumsi negatif tentang sifat karyawan. Menurut teori $\mathrm{X}$, karyawan pada dasarnya 
malas, menghindari tanggung jawab, baru mau bekerja kalau diawasi dan diberi upah. Jika ditinjau dari sisi yang berkaitan dengan kegairahan berinovasi di kalangan karyawan (Ancok, Djamaludin 2012 : 129). Inovasi yang ideal adalah inovasi yang didorong oleh kemauan diri sendiri agar hidup lebih bermakna buat orang banyak, bukan inovasi karena diupah dengan uang atau kenaikan jabatan. Kepemimpinan transformasional dapat membawa organisasi pada inovasi yang ideal ada empat ciri pemimpin transformasional, yakni: idealized influence, intellectual, inspirational, motivation, stimulation, dan individual consideration ( Ancok, Djamaludin 2012 : 130).

Pada sisi lain Daft dan Hanson (1990 : 201) mengemukakan klasifikasi tipetipe perilaku pemimpin yang bisa digunakan oleh pemimpin. Klasifikasi tersebut meliputi gaya- gaya suportif, direktif, berorintasi pada pencapaian dan partisipasi.

Kepemimpinan direktif (Directive leadership) muncul ketika pemimpin memberi tahu para bawahan apa yang harus mereka kerjakan. Perilaku pemimpin meliputi perencanaan, pembuatan jadwal, penentuan tujuan-tujuan kerja dan standarstandar perilaku serta penekanan ketaatan pada peraturan peraturan. Perilaku kepemimpinan direktif mirip dengan gaya kepemimpinan struktur awal yang telah dideskrispsikan sebelumnya.

Kepemimpinan suportif (Supportive leadership) melibatkan perilaku pemimpin yang menunjukan perhatian terhadap kesejahteraan dan kebutuhan pribadi para bawahan. Perilaku kepemimpinan tersebut terbuka, bersahabat dan ramah. Pemimpin menciptakan suasana tim dan memperlakukan para bawahan dengan sama. Kepemimpinan suportif mirip dengan gaya kepemimpinan pertimbangan yang 
telah dideskripsikan sebelumnya

(Daft, Richard L. 2006 : 334).

Kepemimpinan

yang

berorientasi pada pencapaian

(Achievement-orientasi leadership)

muncul ketika pemimpin

menentukan tujuan yang jelas dan

menantang bagi para

bawahan.Perilaku pemimpin

menekankan kinerja kualitas tinggi

dan peningkatan kinerja saat ini.

Pemimpin-pemimpin yang

berorientasi pada pencapaian juga

menunjukkan kepercayaan dalam

diri para bawahan dan membantu

mereka dalam mempelajari cara

mencapai tujuan - tujuan yang

lebih tinggi.

Kepemimpinan partisipatif

(Participative leadership) berarti

pemimpin berkonsultasi dengan

para bawahannya tentang

keputusan - keputusan. Perilaku

pemimpin terdiri atas menanyakan

opini dan saran, mendorong

partisipasi dalam pembuatan

keputusan, dan menemui para

bawahan di lingkungan kerja.

Pemimpin partisipatif mendorong adanya diskusi kelompok dan saran-saran tertulis.

Dari penelitian yang dilakukan Fiedler yang dikutip oleh Prasetyo (2006) ditemukan bahwa kinerja kepemimpinan sangat tergantung pada organisasi maupun ( 27). Apa yang bisa dikatakan adalah bahwa pemimpin bisa efektif ke dalam situasi tertentu dan tidak efektif pada situasi yang lain. Usaha untuk meningkatkan efektifitas organisasi atau kelompok harus dimulai dari belajar, tidak hanya bagaimana melatih pemimpin secara efektif, tetapi juga membangun lingkungan organisasi dimana seorang pemimpin bisa bekerja dengan baik.

Lebih lanjut menurut Prasetyo, gaya kepemimpinan adalah cara yang digunakan dalam proses kepemimpinan yang diimplementasikan dalam perilaku kepemimpinan seseorang untuk mempengaruhi orang lain untuk bertindak sesuai dengan apa yang dia inginkan. Selain itu menurut 
Flippo (1987). Gaya
kepemimpinan juga dapat
didefinisikan sebagai pola tingkah
laku yang dirancang untuk
mengintegrasikan tujuan organisasi
dengan tujuan individu untuk
mencapai suatu tujuan tertentu (p. 394).

Menurut University of Iowa Studies yang dikutip Robbins dan Coulter (2002), Lewin menyimpulkan ada tiga gaya kepemimpinan; gaya kepemimpinan autokratis, gaya kepemimpinan demokratis, gaya kepemimpinan Laissez Faire (Kendali Bebas).

\section{1) Gaya Kepemimpinan}

\section{Autokratis.}

Menurut Rivai (2003),
kepemimpinan
adalah gaya kepemimpinan
yang menggunakan metode
pendekatan kekuasaan dalam
mencapai keputusan dan
pengembangan strukturnya,
sehingga kekuasaanlah yang
paling diuntungkan dalam
organisasi
(p.

Robbins dan Coulter (2002)

menyatakan gaya kepemimpinan autokratis mendeskripsikan pemimpin yang cenderung memusatkan kekuasaan kepada dirinya sendiri, mendikte bagaimana tugas harus diselesaikan, membuat keputusan secara sepihak, dan meminimalisasi partisipasi karyawan (p. 460). Lebih lanjut Sukanto (1987) menyebutkan ciri-ciri gaya kepemimpinan autokratis (pp. 196-198):

a. Semua kebijakan ditentukan oleh pemimpin.

b. Teknik dan langkah-langkah kegiatannya didikte oleh atasan setiap waktu, sehingga langkah-langkah yang akan datang selalu tidak pasti untuk tingkatan yang luas.

c. Pemimpin biasanya membagi tugas kerja bagian dan kerjasama setiap anggota.

Sedangkan menurut Handoko dan Reksohadiprodjo (1997), ciri - ciri gaya 
kepemimpinan autokratis (p. 304):

1. Pemimpin kurang memperhatikan kebutuhan bawahan.

2. Komunikasi hanya satu arah yaitu kebawah saja.

3. Pemimpin cenderung menjadi pribadi dalam pujian dan kecamannya terhadap kerja setiap anggota.

4. Pemimpin mengambil jarak dari partisipasi kelompok aktif kecuali bila menunjukan keahliannya.

\section{2) Gaya kepemimpinan}

\section{Demokratis / Partisipatif}

Kepemimpinan

demokratis ditandai dengan adanya suatu struktur yang pengembangannya

menggunakan pendekatan pengambilan keputusan yang kooperatif. Dibawah kepemimpinan demokratis bawahan cenderung bermoral tinggi, dapat bekerja sama, mengutamakan mutu kerja dan dapat mengarahkan diri sendiri (Rivai, 2006, p. 61).

Menurut Robbins dan Coulter (2002), gaya kepemimpinan demokratis mendeskripsikan pemimpin yang cenderung mengikutsertakan karyawan dalam pengambilan keputusan, mendelegasikan kekuasaan, mendorong partisipasi karyawan dalam menentukan bagaimana metode kerja dan tujuan yang ingin dicapai, dan memandang umpan balik sebagai suatu kesempatan untuk melatih karyawan (p. 460).

Jerris (1999) menyatakan bahwa gaya kepemimpinan yang menghargai kemampuan karyawan untuk mendistribusikan knowledge dan kreativitas untuk meningkatkan servis, mengembangkan usaha, dan menghasilkan banyak keuntungan dapat menjadi motivator bagi karyawan dalam 
bekerja (p.203).

Ciri-ciri gaya kepemimpinan demokratis (Sukanto, 1987, pp. 196-198):

a. Semua kebijaksanaan terjadi pada kelompok diskusi dan keputusan diambil dengan dorongan dan bantuan dari pemimpin.

b. Kegiatan - kegiatan didiskusikan, langkahlangkah umum untuk tujuan kelompok dibuat, dan jika dibutuhkan petunjuk-petunjuk teknis pemimpin menyarankan dua atau lebih alternatif prosedur yang dapat dipilih. c. Para anggota bebas bekerja dengan siapa saja yang mereka pilih dan pembagian tugas ditentukan oleh kelompok.

Lebih lanjut ciri-ciri gaya kepemimpinan demokratis (Handoko dan

Reksohadiprodjo, 1997, p. 304): a. Lebih memperhatikan bawahan untuk mencapai tujuan organisasi.

b. Menekankan dua hal yaitu bawahan dan tugas.

c. Pemimpin adalah obyektif atau fact-minded dalam pujian dan kecamannya dan mencoba menjadi seorang anggota kelompok biasa dalam jiwa dan semangat tanpa melakukan banyak pekerjaan.

3) Gaya Kepemimpinan Laissez - faire (Kendali Bebas)

Gaya kepemimpinan kendali bebas mendeskripsikan pemimpin yang secara keseluruhan memberikan karyawannya atau kelompok kebebasan dalam pembuatan keputusan dan menyelesaikan pekerjaan menurut cara yang menurut karyawannya paling sesuai (Robbins dan Coulter, 2002, p. 460). 


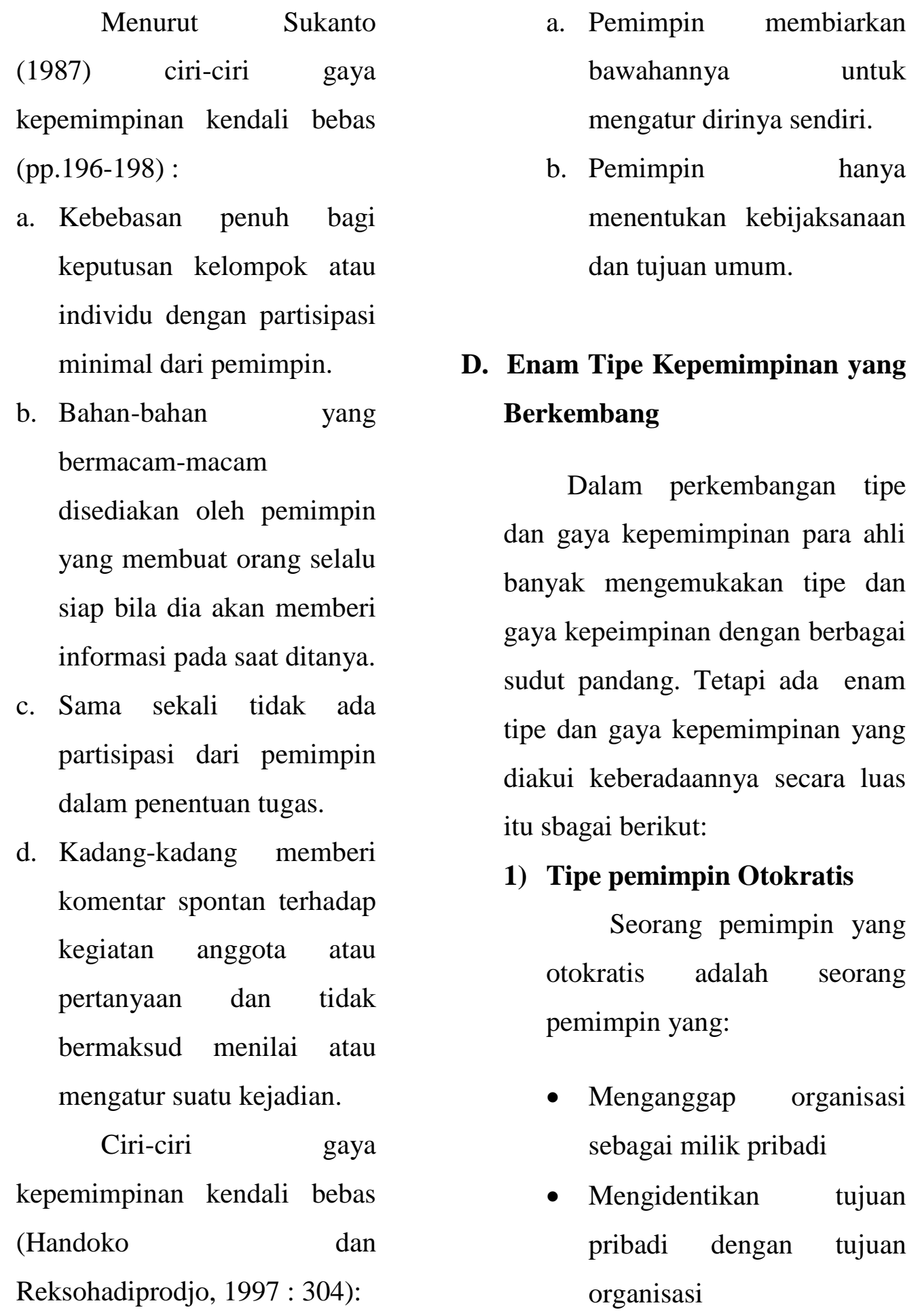


- Menganggap bawahan sebagai alat semata- mata

- Tidak mau menerima kritik, saran, dan pendapat

- Terlalu bergantung kepada kekuasaan formalnya

- Dalam tindakan penggerakannya sering mempergunakan pendekatan yang mengandung unsur paksaan dan punitif (bersifat menghukum

\section{2) Tipe Militeristis}

Yaitu seorang pemimpin yang bertipe militeristis adalah seorang pemimpin yang memiliki sifat- sifat:

- Sering mempergunakan sistem perintah dalam menggerakkan

bawahannya.

- Senang bergantung pada pangkat dan jabatan dalam menggerakkan bawahannya.

- Senang kepada formalitas yang berlebih - lebihan.
- Menuntut disiplin yang tinggi dan kaku dari bawahan.

- Sukar menerima kritikkan dari bawahan.

- Menggemari upacaraupacara untuk berbagai acara dan keadaan

\section{3) Tipe Paternalistis}

Yaitu seorang pemimpin yang:

- Menganggap bawahannya sebagai manusia yang tidak dewasa.

- Bersikap terlalu melindungi.

- Jarang memberikan kesempatan kepada bawahannya untuk mengambil keputusan dan inisiatif.

- Jarang memberikan kesempatan kepada bawahannya untuk mengembangkan daya kreasi dan fantasinya.

- Sering bersikap maha tahu. 


\section{4) Tipe Kharismatis}

Hingga kini para pakar belum berhasil menemukan sebab - sebab mengapa seorang pemimpin memiliki kharisma, yang diketahui adalah bahwa pemimpin yang demikian mempunyai daya tarik yang amat besar dan karenanya pada umumnya mempunyai pengikut yang jumlahnya sangat besar.Karena kurangnya pengetahuan tentang sebab musabab seorang menjadi pemimpin yang kharismatis, maka sering dikatakan bahwa pemimpin yang demikian diberkahi dengan kekuatan gaib (supernatural powers).

\section{5) Tipe Laissez Faire}

$$
\text { Yaitu seorang yang }
$$

bersifat:

- Dalam memimpin organisasi biasanya mempunyai sikap yang permisif, dalam arti bahwa para anggota organisasi boleh saja bertindak sesuai dengan keyakinan dan hati nurani, asal kepentingan bersama tetap terjaga dan tujuan organisai tetap tercapai.

- Organisasi akan berjalan lancar dengan sendirinya karena para anggota organisasi terdiri dari orang- orang yang sudah dewasa yang mengetahui apa yang menjadi tujuan organisasi, sasaran yang dicapai, dan tugas yang harus dilaksanakan oleh masing- masing anggota.

- Seorang pemimpin yang tidak terlalu sering melakukan intervensi dalam kehidupan organisasional.

- Seorang pemimpin yang memiliki peranan pasif dan membiarkan organisasi berjalan dengan sendirinya. 


\section{6) Tipe Demokratis}

Yaitu tipe yang bersifat:

- Dalam proses penggerakkan bawahan selalu bertitik tolak dari pendapat bahwa manusia adalah makhluk termulia di dunia.

- Selalu berusaha mensinkronisasikan kepentingan dan tujuan organisasi dengan kepentingan dan tujuan pribadi dari para bawahannya.

- Senang menerima saran, pendapat bahkan kritik dari bawahannya.

- Selalu berusaha untuk menjadikan bawahannya lebih sukses dari padanya.

- Selalu berusaha mengutamakan kerjasama dan kerja tim dalam usaha mencapai tujuan.

- Berusaha mengembangkan kapasitas diri pribadinya sebagai pemimpin.
- Para bawahannya dilibatkan secara aktif dalam menentukan nasib sendiri melalui peran sertanya dalam proses pengambilan keputusan.

(https://adenrabani.wordpress .com/.../ 15-02-2017).

\section{E. Faktor-faktor Mempengaruh Tipe dan Gaya Kepemimpinan}

Hasil penelitian yang dilakukan oleh Goldsmith, sebagaimana yang dikutip oleh Aunurrahman (2009) menunjukkan bahwa pemimpin yang mampu menumbuhkan suasana dialogis, kesetaraan, dan tidak arogan atau nondefensif serta selalu berupaya mendorong sikap positif, akan dapat mendorong terjadinya keefektifan proses pembelajaran.

Oleh sebab itu, pemimpin pendidikan ketika mengaplikasikan gaya atau aktivitas kepemimpinannya sangat tergantung pada pola organisasi yang melingkupinya. Dan juga dalam melaksanakan aktivitasnya 
pemimpin dipengaruhi oleh berbagai macam faktor. Faktor-faktor tersebut sebagaimana sebagaimana yang dikutip Nanang fattah (2001), sebagai berikut:

1. Kepribadian (personality), pengalaman masa lalu dan harapan pemimpin, hal ini mencakup nilai-nilai, latar belakang dan pengalamannya akan mempengaruhi pilihan akan gaya kepemimpinan.

2. Harapan dan perilaku atasan.

3. Karakteristik, harapan dan perilaku bawahan mempengaruhi terhadap apa gaya kepemimpinan.

4. Kebutuhan tugas, setiap tugas bawahan juga akan mempengaruhi gaya pemimpin.

5. Iklim dan kebijakan organisasi mempengaruhi harapan dan perilaku bawahan.

6. Harapan dan perilaku rekan.

\section{F. Model Kepemimpinan Dakwah}

Pada dasarrnya manusia itu diciptakan hanyalah untuk menyembah dan mengabdi kepada
Allah, sehingga segala aktivitas manusia adalah harus mendapat dan mencari keridhaan dari Allah SWT. Begitu juga dengan manusia yang dinaikkan sedikit derajatnya dari mansia yang lain untuk menjadi pemimpin tetap hanya untuk menyembah dan mengabdi kepada Allah. Itulah sebabnya asas dari kepemimpinan manajemen ilahiyah sebagai berikut:

1) Kewenangan dipertanggung jawabkan kepada Allah.

2) Amanah untuk memakmurkan bumi ini.

3) Iman.

4) Taqwa.

5) Musyawarah

6) Keadilan.

Pemimpin dalam lingkup manajemen ilahiyah adalah pengabdian, serta mengutamakan keselamatan rakyat sebagaimana yang dilakukan Nabi Muhammad SAW., firman Allah dalam Alquran Surah At Taubah ayat 128 "Sungguh telah datang kepadamu seorang Rasul dari kaummu 
sendiri, berat terasa olehnya penderitaanmu, sangat menginginkan (keimanan dan keselamatan) bagimu, Amat belas kasihan lagi Penyayang terhadap orang-orang mukmin”.

Konsep kepemimpinan juga dikemukakan dalam banyak ayat antara lain dalam Alquran Surah Al-An'am ayat 165 "Dan Dia lah yang menjadikan kamu penguasapenguasa di bumi dan Dia meninggikan sebahagian kamu atas sebahagian (yang lain) beberapa derajat, untuk mengujimu tentang apa yang diberikan-Nya kepadamu. Sesungguhnya Tuhanmu Amat cepat siksaan-Nya dan Sesungguhnya Dia Maha Pengampun lagi Maha Penyayang".

Kemudian dalam Alquran surah Shad ayat 26 yang berbunyi:

" Hai Daud, Sesungguhnya Kami menjadikan kamu khalifah (penguasa) di muka bumi, Maka berilah keputusan (perkara) di antara manusia dengan adil dan janganlah kamu mengikuti hawa nafsu, karena ia akan menyesatkan kamu dari jalan Allah. Sesungguhnya orang-orang yang sesat dari jalan Allah akan mendapat azab yang berat, karena mereka melupakan hari perhitungan".

\section{Dalam Alquran Surah An-} Nisa ayat 59 berbunyi: "Hai orangorang yang beriman, taatilah Allah dan taatilah Rasul (Nya), dan ulil amri di antara kamu. kemudian jika kamu berlainan Pendapat tentang sesuatu, Maka kembalikanlah ia kepada Allah (Al Quran) dan Rasul (sunnahnya), jika kamu benarbenar beriman kepada Allah dan hari kemudian. yang demikian itu lebih utama (bagimu) dan lebih baik akibatnya".

Dalam Surah Ali Imran
ayat 28 berbunyi: "Janganlah
orang-orang mukmin mengambil
orang-orang kafir menjadi wali
dengan meninggalkan orang-orang
mukmin. barang siapa berbuat
demikian, niscaya lepaslah ia dari


pertolongan Allah, kecuali karena (siasat) memelihara diri dari sesuatu yang ditakuti dari mereka. Dan Allah memperingatkan kamu terhadap diri (siksa)-Nya. dan hanya kepada Allah kembali (mu)".

Rasullah bersabda bahwa setiap manusia adalah pemimpin sebagai bunyi Hadis yaitu "setiap kalian adalah pemimpin dan setiap pemimpin harus bertanggung jawab atas kepemimpinannya" (Mutafaqun' Alaih dari Ibnu Umar)".

Sebagai sedikit gambaran bagaimana Rasulullah ketika memulai membangun masyarakat Islam yang dilakukan beliau adalah 1) mengesakan Allah, 2) mensucikan dan membersihkan jiwa, 3) menguatkan barisan dan 4) meleburkan kepentingan pribadi ke dalam kepentingan jemaah. Selanjutnya pada tanggal 16 Agustus awal tahun pertama Hijriah dilaksanakan khutbah Jum'at pertama, sekaligus juga berdirinya negara Islam. Rasul telah menetapkan dasar negara, yaitu taqwa kepada Allah Yang Maha Esa, artinya segala sesuatu harus berjalan di atas garis Allah, yang diantaranya Politik negara berdasarkan atas :

1) Al-Adalatul Insaniyah (perikemanusiaan).

2) Asy-Syura (demokrasi)

3) Al-Wahdatul Islamiyah (persatuan Islam).

4) Al-Ukhuwah Islamiyah (persaudaraan Islam).(AsySyaikh Khalil Yasien, 1995 : 105 ).

Model kepemimpinan dakwah tidak hanya berpegang pada satu gaya sehingga dapat dikatakan bahwa kepemimpinan dakwah sebagai salah satu gaya kepemimpinan. Paradigma gaya kepemimpinan dakwah Nabi Muhammad SAW. wajib menjadi rujukan bagi pemimpin dakwah yaitu syura (permusyarawatan), hurriyyah al-Kalam (kebesan berekspresi dengan 'Adab al- 
Ikhtilaf) dan 'Adl bil qisth (keadilan dengan kesetaraan). Semua komponen tersebut tidak terpisahkan dalam menjalankan kepemimpinan dakwah.

Jika dirangkai gaya kepemimpinan dakwah merujuk kepada gaya kepemimpinan Rasulullah adalah gaya tiga plus lima. Sebagaimana yang dikekukan Ismail Noor (1999), tiga gaya itu adalah permusyarawatan, keadilan dan kebesan berekpresi. Kemudian dirangkai dengan lima ajaran yaitu integritas pribadi, perbaikan hubungan, daya kepemimpinan, prilaku etis dan peningkatan moral melalui pengetahuan spiritual.

\section{Simpulan}

Dari pemaparan di atas dapat diambil beberapa kesimpulan sebagai berikut :

- Kepemimpinan adalah usaha mempengaruhi sekelompok orang/anggota kelompok dengan gaya dan cara metode apa saja agar kelompok orang/anggota kelompok tersebut melakukan aktivitas untuk mencapai tujuan bersama.

- Dinamika kepemimpinan yang terus berkembang seiring dengan perkembangan jaman, ilmu pengetahuan dan teknologi melahirkan kualitas kepemimpinan, tipe dan gaya kepemimpinan yang cukup beragam.

- Tipe dan Gaya kepemimpinan adalah cara yang digunakan dalam proses kepemimpinan yang diimplementasikan dalam perilaku kepemimpinan seseorang untuk mempengaruhi orang lain untuk bertindak sesuai dengan apa yang dia inginkan.

- Pada dasarnya ada tiga gaya kepemimpinan yaitu gaya gaya kepemimpinan autokratis, tipe dan gaya kepemimpinan demokratis, gaya kepemimpinan Laissez Faire, yang selanjutnya melahirkan banyak tipe dan gaya kepemimpinan.

- Gaya kepemimpinan dakwaha adalah pemimpin yang mampu 
membawa masyarakat kepada

kesuksesan dalam mendapat ridha dari Allah SWT. Dalam hal ini pemimpin akan selalu berupaya untuk mencapai kemaslahatan dan kesejahteraan pengikutnya demi keselamatan hidup dunia dan akhirat. Dengan demikian gaya seoarang pemimpin dakwah dan pendidikan tidak akan terlepas dari tiga hal yaitu sebagai pembimbing, sebagai model dan sebagai praktisi.

- Gaya kepemiminan dakwah merupakan sebuah model dan gaya kepemimpinan dengan formulasi tersendiri.

\section{Daftar Pustaka}

Ancok, Djamaludin. (2012). Psikologi Kepemimpinan \& Inovasi.Jakarta : Erlangga.

Cacioppe, Ron. 1997." Ledership Moment by Moment!" Leadership \& Organisasi Development Journal, 18 (7), 335-345.

Daft, Richard L. 2006. Management .Jakarta : Salemba Empat.
Hanson, E Mark,(1991) Educational Administration And Organizational Behavior, USA Allyn and Bacon.

http://www.kompasiana.com/rudisala msinulingga/gaya-gaya kepemimpinan 54f79ceca33311 df1d8b4583 15-2-2017.

(https://adenrabani.wordpress.com/.../ 15-02-2017).

Kouzes,M James dan Barry Z. Posner.(2004). The Leadership Challenge.Jakarta : Erlangga.

Michael F Di Paola, Wayne K. Hoy, 2015, Leadership and School Quality, Information Age Publishing, INC, The Ohio State Universitas USA.

Robert Kreitner, 1989, Management, $4^{\text {th }}$ edision, Houghton Mifflin Company : Boston.

Rivai H. Veithzal, Murni Sylviana. 2009. Education Management Analisis Teori dan Praktik. Jakarta : PT. RajaGrafindo Persada.

Stoner .2006.The Truth About Managing People and Nothing But The Truth. New Jersey: Prentice. Inc.

Yunus, Jamalulail. (2009). Leadership Model.Malang: UIN Malang Press. 